\title{
Hispanics and Higher Education: An Overview of Research, Theory, and Practice
}

\author{
Amaury Nora and Gloria Crisp
}

\section{Introduction}

According to the 2000 census, there are currently 35.3 million Hispanics living in the United States, a near 60\% increase from just 10 years earlier (Pew Hispanic Center, 2005). The largest subgroup of Hispanics is of Mexican origin (66\%), followed by groups from Central or South America (15\%), Puerto Rico (9\%), Cuba (4\%), and other Hispanic countries (6\%) (US Department of Commerce, 2001). While immigration has been the major contributor to this increase in the past 4 decades (National Research Council, 2006), it is believed that future increases in the Hispanic population will be driven primarily by high birth rates of second- and third-generation citizens (Pew Hispanic Center, 2005). A substantial Hispanic population will result, as it is projected that in the next 50 years this group will account for $51 \%$ of the population growth, making one fourth of the total US population by 2050 of Hispanic origin (Llagas \& Snyder, 2003).

Latinos lag behind other groups educationally (Fry, 2004). In 2000, only $10 \%$ of Hispanics aged 25-29 had earned a bachelor's degree or higher compared to 34\% of Whites and 18\% of African-Americans (Llagas \& Snyder, 2003). This variation in postsecondary educational attainment has caused substantial labor market inequalities with this population. In contrast to African-Americans who continue to suffer from discrimination that contributes to disparities in earnings, Hispanics are presently paid comparably to Whites given the same amount of education (National Research Council, 2006). Regardless, the low levels of formal schooling earned have contributed to the overrepresentation of the Latino population in low-skill occupations that pay less, and have higher unemployment rates than other groups (6.8\% for Hispanics compared to $4.3 \%$ for Whites). Currently, Hispanic households own less than 10 cents for every dollar in wealth owned by White households (Pew Hispanic Center, 2005). Unless college graduation rates of Hispanic students show significant increases, the unemployment and poverty rates for this group are sure to rise. In Texas, for example, it is projected that by 2030 the average household will be US\$4,000 poorer than in 1990 (in constant dollars), increasing the poverty rate nearly 3\% (President's Advisory Commission, 2002). 
Although Latinos are among the least educated groups in the United States, they are making a significant impact in schools at all levels (Laden, 2004). In 2000, over 11.4 million school-aged Hispanic children resided in the country, representing $16 \%$ of all children. By 2020, it is projected more than $20 \%$ of all children under age 18 in the United States will be Hispanic (Llagas \& Snyder, 2003). Differences in the educational experiences of Latinos are seen as early as preschool, as Hispanic children are significantly less likely than other children to attend preschool programs (Pew Hispanic Center, 2005). These differences are consistent throughout Hispanic students' K-12 education; the percentage of 16-24-year-old dropouts who leave school before earning a high school credential is consistently higher for Hispanic students. It is believed that roughly $48 \%$ of Hispanic students enrolled in middle school in the eighth grade will not return to school to begin their high school education. Moreover, Mexican American students failing to earn a high school credential has been estimated at nearly 50\% (using ninth grade enrollment as the baseline year). And finally, of those Latino students that survive high school and graduate, only a mere $35-40 \%$ enroll in college (Arbona \& Nora, 2007; Nora, Barlow \& Crisp, 2006).

The low high school completion rate, particularly among immigrants, is negatively impacting Hispanic postsecondary enrollment. Less than half of all Hispanic high school students in this country currently qualify to enroll in 4-year institutions. Of those, only between $30 \%$ and $40 \%$ (depending on geographic region) are enrolling in college immediately following graduation (President's Advisory Commission, 2002). This figure equates to only $22 \%$ of the $18-24$-year-old Hispanic students in this country enrolled in college in 2000. The percentage of eligible Hispanic students attending college appears to be on the rise, at least at the community college level (Fry, 2005). In 2000, 36\% of high school completers enrolled in college, up from only $27 \%$ in 1985 (Llagas \& Snyder, 2003).

Figures from the 2000/01 California Postsecondary Education Commission (CPEC) provide a sobering illustration of Hispanic postsecondary educational pathways in the state. According to CPEC, of every 100 Hispanic students who graduate from California high schools only 40 enroll at a postsecondary institution. Of these 40 students, 30 begin at one of the state's community colleges, three are admitted and enroll at the University of California, and seven at California State University system campuses (Solorzano et al., 2005). Regrettably, the figures present in California appear to be reflective of Hispanic students around the country.

Discrepancies are also seen in the types of institutions Latino students attend when compared to White students. Presently, Latinos are much more likely to attend community colleges or less selective 4-year universities than White students (Pew Hispanic Center, 2005). In 2004, 66.2\% of Hispanic students enrolled at an open-door institution or community college, compared to $45 \%$ of White students. Although similar percentages attended highly selective colleges, 9\% of White students attended selective 4-year institutions compared to $6 \%$ of Hispanics (Fry, 2004). It is important to note that these disparities are only partially attributable to differences in academic preparation, as these enrollment differences are seen not considering high school preparation (Pew Hispanic Center, 2005). 
At the graduate level, Hispanics earn a mere $4 \%$ of all master's degrees, $3 \%$ of doctoral degrees, and $5 \%$ of professional degrees. Compared to national averages, Hispanic students are more likely to earn master's degrees in education (33\% versus $27 \%$ ) and are less likely to earn their master's degree in engineering, health professions, business, and computer information sciences. Similarly, at the doctoral level Hispanics are earning higher than average numbers of degrees in education and psychology but are less likely to earn a terminal degree in engineering (7\% for Hispanics compared to $12 \%$ nationally), physical science, and science technologies (6\% compared to $9 \%$ nationally) (Llagas \& Snyder, 2003).

The importance of reaching a higher level of academic accomplishment past a high school diploma is evident in that it provides increased opportunities for career development and enhances the choices that are made available to those with an undergraduate degree. Its importance is even much more evident in that advancement and salary are highly associated with a 4-year degree. In 2000, among people 25 years and older, $1.7 \%$ of those with a bachelor's degree or higher were unemployed in contrast to $3.5 \%$ of high school graduates and $6.4 \%$ of high school dropouts. Those with higher levels of education garner better incomes. In 1999 the median annual income for year-round full-time male workers was about $\$ 25,000$ for high school dropouts, $\$ 33,000$ for high school graduates, and $\$ 53,000$ for college graduates (the median incomes for women were $\$ 17,000, \$ 23,000$, and $\$ 38,000$, respectively). Overall, a college graduate is estimated to earn one million dollars more in income and benefits over a lifetime than a high school graduate (National Center for Educational Statistics, 2001).

Improving access and success of Hispanic students at all postsecondary levels has been declared a national priority by the Clinton and Bush administrations (Fry, 2004). But substantial gaps exist in our knowledge base relative to understanding and serving the unique needs of Latino students in higher education (Hurtado \& Ponjuan, 2005). In order to improve access for Hispanic students in higher education a better understanding of the current issues surrounding access and the in- and out-of-college experiences which lead to persistence for this group is needed. More specifically, an understanding of the multidimensional components of Hispanic students' academic experiences is critical (Castellanos \& Jones, 2004).

\section{Current Barriers to College Access}

\section{Academically Related Barriers}

\section{Dropping Out of High School}

It has been reported that in the last 20 years there has been a substantial increase in the participation of minorities in higher education (Harvey, 2003). Despite these reported increases, Hispanic youth continue to show lower college participation and graduation rates than their African-American and White counterparts. Among the 
general population of individuals between the ages of 25 to 29, the percentage of those with at least a bachelor's degree in 2000 was lower for Hispanics (10\%) as compared to African-Americans (18\%) or Whites (34\%) (National Center for Educational Statistics, 2002).

Not surprisingly, a major reason for the small numbers of Hispanic students enrolling in college is grounded in the fact that there is a high incidence of high school dropout behavior among Hispanics. Data from the National Center for Education Statistics (2002) indicate that in 2000 the school dropout rates among 16-24 years olds was much higher for Hispanics (28\%) than for African-Americans $(13 \%)$ or Whites $(7 \%)$. It is estimated that the dropout rates among Hispanics and African-American students enrolled in inner-city or urban school districts may be as high as $56 \%$ (National Center for Education Statistics, 2000). Utilizing the NELS 88:2000 database, Arbona and Nora (2005) examined those factors that would impact on whether or not Hispanic students attended college, whether or not they enrolled initially in a 2- versus a 4-year institution, and whether or not they graduated 6 years following their initial enrollment in college. In that study, the authors found that only $56 \%$ of students starting the eighth grade managed to graduate with a high school diploma.

\section{Academic College Preparation}

Using information from the National Educational Longitudinal Study (NELS), Swail et al. (2005) analyzed the high school academic preparation of Hispanic students and its impact on their postsecondary educational attainment. In their study, Swail et al. noted substantial differences between Latino \& White students with regard to their precollege academic preparation. Those differences included the number of remedial courses taken, scores on the college qualification index, their high school curricula, placement in advanced courses, and testing for college placement. In sum, Latino students were less academically prepared for high school, during high school and, ultimately, for college as compared to White students. Evidence of this lack of preparation was evident in that only $12 \%$ of Latino students scored in the top quartile of the NELS reading and mathematics tests compared to nearly a third of White students. Moreover, scores on the College Qualification Index (based on cumulative academic course grade point average (GPA), senior class rank, NELS aptitude test scores, and American College Test (ACT) or Scholastic Aptitude Test (SAT) exam scores) indicated a $19 \%$ gap between Latino and White students. Without the appropriate academic background needed to enter and compete in college, it is no wonder that so few Hispanic students go on to college.

In a study funded by the Association for Institutional Research (AIR), Arbona and Nora (2005) further substantiated that significant factors leading to enrollment in college among Hispanic students included following a more rigorous academic curriculum or just taking an academic track while in high school. At the same time, Zarate and Gallimore (2005) also found that the enrollment in college for Hispanic students was driven by their academic achievement in high school. 


\section{Academic Performance}

While academic achievement might be a significant predictor of college enrollment, Zarate and Gallimore (2005) believe that it is because studies to date have relied almost solely on high school academic achievement measures. The problem with this approach is that other noncognitive factors are often excluded from any data analyses leaving mainly precollege academic performance measures to predict Hispanic student participation. What the higher education community is left with is that very little is known about what differentiates Latino/Latina students who enroll in college and those that do not (Zarate \& Gallimore, 2005). Policymakers, educators, and researchers who focus their attention on Hispanic students after they have been admitted to college are only addressing part of the problem and may be overlooking what is creating barriers that limit the degree of access for Hispanics (Nora \& Oliva, 2004).

\section{Socioeconomic Barriers/Cultural and Social Capital}

While cognitive stumbling blocks play a major role in accessing higher education, other noncognitive factors also point to barriers (economic, cultural, and social) that are equally as influential in denying access to higher education. In 2000, 28\% of all Hispanic children in the United States were living in poverty (Llagas \& Snyder, 2003). Researchers argue that, in addition to economic circumstances, college decisions of minority and low-income students are limited due to a lack of cultural and social capital. That is, these students may not have the cultural knowledge or access to informal social networks needed to engage in seeking and acquiring the necessary college-related information that could provide easier access to college participation (Gonzalez et al., 2003).

In contrast to the parents of White and/or upper-middle-class students who can draw on their own personal experiences in higher education and can count on social networks to improve their children's abilities to successfully enroll in, and graduate from, college, low-income Hispanic parents typically prepare for college later in their students' academic careers. Concomitantly, these same families face more obstacles with fewer resources that can assist their children in achieving their educational aspirations (Auerbach, 2004).

A recent qualitative study conducted by Gonzalez et al. (2003) examined how the relationships established between school personnel and families more often than not affect college opportunities for Latina students. Using life history research methods, the school experiences of Latina students were investigated. The findings indicated that the lack of social capital, or limited assets, ultimately impacts on the student's actual and/or perceived access to college. More specifically, students who did not have access to high volumes of social capital early in their academic careers were often neglected in the college planning process. Research by Gándara (1998, 2002) had earlier found that the single most influential barrier to access for 
Hispanic students in California is not having the instrumental knowledge of the steps involved in enrolling in postsecondary education. Access to guidance counselors and teachers has been found to play a critical role in the college attendance decisions of Latino students (Gonzalez et al., 2003).

Gonzalez et al. (2003) further found that, among Latina community college students that managed to overcome those barriers and enroll in college, these students continued to endure institutional neglect resulting from an inadequate curriculum in their secondary education, were tracked into remedial or English as Second Language (ESL) courses in college, had negative experiences with faculty, and had limited or negative contact with college counselors.

\section{Increasing Tuition and Lack of Financial Aid}

One key contributor to access for minorities and low-income students is financial assistance or, more succinctly, college affordability (Nora, 2004b). According to a report released by the College Board (2003), average tuition and fees have risen almost $50 \%$ at public 4-year colleges and $22 \%$ at community colleges over the past 10 years (1993-2003). Moreover, this upward trend continued for the 2003/04 academic year; average tuition and fees rose an additional $15 \%$ at both 2 - and 4-year public colleges and universities. Santiago \& Brown (2004) argue that the growth in tuition and fees will continue due to gradual decreases in state funding for higher education.

To pay for college, Hispanic students have relied heavily on support from the federal government to meet the costs of tuition, books, housing, etc. According to data from the National Postsecondary Student Aid Study (NPSAS), for the 2003/04 academic year $80 \%$ of Hispanic undergraduates applied for financial aid, of which $63 \%$ were awarded some form of financial assistance. Although proportionately Latinos were more likely to receive federal aid than all of the other racial groups combined, they received the lowest average aid award of any racial/ethnic group (i.e., $\$ 5,415$ for Latino students compared to $\$ 6,230$ for Whites). It is evident that grants and loans are critical for Latinos as $50 \%$ of these students receive grants and $30 \%$ receive loans. However, it should be noted that the average loan amount received was $\$ 5,620$ compared to only $\$ 3,810$ in grants (Santiago \& Cunningham, 2005).

\section{Acculturative Stress}

Several Hispanic researchers have identified noncognitive features that also have a predictive nature related to college enrollment (Contreras, 2005; Zarate \& Gallimore, 2005; Arbona \& Nora, 2005). As is most often anticipated, parental expectations and aspirations and socioeconomic status (SES) have been associated with college attendance. In examining differences in achievement between Latino and White college-bound (SAT and AP test takers) students with respect to background and achievement, Contreras (2005) reveals the gaps in "inputs" Latino 
students possess regarding disparate income, parent education levels, access to Advanced Placement courses, and scores on standardized exams. In addition, the author notes that Latinos reported lower self-perceptions with regard to potential and ability than White students with comparable ability.

Research by Smedley Myers, Harrell (1993) found that minority status among Hispanics and African-American students undermine a student's academic confidence that only leads the student to question his or her ability to meet the demands of attending a highly competitive university. If this situation were not enough, minority students' concerns among those that manage to enroll in college are only worsened by the negative expectations of their nonminority faculty and peers.

Early work by Nora \& Lang (1999) identified the student's academic selfefficacy as a major contributor of college enrollment. The authors believed a student's perception that they possessed the academic ability to attend college was captured through a measure of the academic rigor of the student's curriculum in high school. In this sense, psychosocial factors may also play a role in deciding whether to enroll in college or not.

A longitudinal study following a random selection of Latino/Latina students from kindergarten through college investigated the possibility that gender differences were at play when it came to those factors predicting college enrollment (Zarate \& Gallimore, 2005). The authors indicated that while academic achievement, language proficiency, and parental factors consistently predicted college enrollment for Latinos, the pursuit of college counseling services and teacher-rated classroom performance were found to significantly affect college going for Latinas.

\section{Parental Support and Encouragement}

Research has consistently demonstrated that parental support is critical to a student's decision to apply and enroll in college (Gándara, 1995, 2002; Hossler et al., 1999; Hossler \& Stage, 1992; McDonough, 1997; Perna, 2000). Hossler et al. (1999) provided evidence that Latino parents with low socioeconomic levels or who lack a formal education does not necessarily lead to low college aspirations on the part of their children.

Ceja (2004) examined the importance of the role that parents play in the development of the educational aspirations of Chicana students. Interviews with 20 Chicana students revealed that each of the students indicated a belief that they were provided parental support to seek a college education. Although the majority of the Latino parents in the study had no previous formal college experience, Chicana students indicated their parents had still found unique ways of influencing their thoughts and college aspirations.

Using a multiple case study design, Cejda et al. (2002) investigated those factors that influence Hispanic students' decisions to attend and persist in Hispanic Serving Institutions (HSIs). Familial support and encouragement as well as a motivation to "not repeat" or "not be like" other family members that did not attend college were found as primary influences on students' college-going decisions. 
Arbona \& Nora (2005), however, found that parental expectations were not as influential as has been found in the past. The researchers found that several variables distinguished Hispanic students who attended college from their peers who did not attend college. Students whose native language was Spanish were more likely than not to attend college. The result was thought to be consistent with other studies in that second-generation Hispanic students tend to show higher academic achievement than their later-generation counterparts (Ortiz, 1986). Students' academic goals as well as their high school preparation also predicted their college enrollment. Students who followed a more rigorous academic curriculum in high school and who had expectations of obtaining a bachelor's degree while in the tenth grade were more likely to attend college than students with lower academic achievement and expectations.

Perna \& Titus (2005) also found that parental encouragement, defined as a mother's educational expectations and her involvement in her child's precollege education, were unrelated to college enrollment for Hispanic students. The authors speculate that this contradictory finding may be at least partially attributed to the fact that parental involvement is typically defined as a single indicator, rather than a multidimensional construct.

\section{The Transfer Function and Hispanic Students}

Another issue of concern regarding Hispanic participation in higher education is their disproportionate representation in 2-year colleges (Chronicle of Higher Education, 2001; Nora et al., 1999). In the fall of 2000, 58\% of Hispanics enrolled in colleges were attending 2-year institutions whereas the same was true for $42 \%$ of African-American and 36\% of White students (Harvey, 2003). Contrary to what was once thought, community colleges have not served as the gateway to a bachelor's degree for large numbers of lower-income and ethnicminority populations. Approximately $25 \%$ of Hispanic students in the Beginning Postsecondary Students Longitudinal Study (BPS:96/01) who attended a 2-year college intended to transfer to a 4-year institution and obtain a bachelor's degree. However, 6 years after first enrolling in the community college only $6 \%$ had obtained a bachelor's degree and an additional $12 \%$ remained enrolled in college (Hoachlander et al., 2003).

One of the major barriers to graduation for Hispanic students appears to be transferring from the community college to the university. Although $71 \%$ of Latino vstudents attending community colleges report desiring to transfer to a 4-year institution, currently only 7-20\% actually transfer (National Center for Educational Statistics, 2003). Contributing factors to the poor transfer rates include an absence of a "transfer culture," a lack of articulation agreements between 2- and 4-year colleges, poor academic guidance and counseling, the myth that completing an Associates of Arts degree will fulfill transfer requirements, and low expectations of community college faculty (Ornelas \& Solórzano, 2004). 


\section{Barriers/Limitations in College Choice}

Not only is preparing for college an important issue; choosing which type of college to attend, which campus will provide a good fit, and which student populations are more likely to be tolerant or accepting is just as equally important for Latino students. The choice of college that a Latino student makes affects so many different aspects of a student's life, from the academic and social integration and adjustment of that student to his or her academic performance and, ultimately, his or her degree attainment. Studies have examined such issues as selectivity patterns among Latino students as well as an examination of the different factors that students consider in making a final choice.

\section{The Choice Process}

In comparing Hispanic and White freshman with average or near-average level of high school preparatory work, a report by the Pew Hispanic Center (2005) revealed that Hispanics tend to choose less selective colleges and universities. Hurtado et al. (1997) investigated the differences in college access and choice among students of different racial/ethnic groups using the National Educational Longitudinal Study (NELS:88/92) and the Beginning Postsecondary Student Longitudinal Study (BPS:90/92). The investigators found significant group differences in the number of colleges students applied to, preparation behaviors, and the decision to attend their first-choice institution. Specifically, Latino students applied to fewer colleges, were less likely to engage in an extensive search and college choice process, had the lowest goal aspirations, and were less likely to enroll in college immediately following graduation when compared to other ethnic groups.

A qualitative study by Immerwahr (2003) identified several intangible impediments faced by Hispanic students that influence their college choices including a lack of knowledge about higher education in general, misinformation on admissions requirements and financial aid, and competing options. Many of the Hispanic students interviewed indicated they failed to receive adequate guidance from parents or counselors. As a result, many students were misinformed about higher education which led to poorly informed choices. Additionally, competing options were found to keep students away from higher education as many of the students interviewed were already offered full-time employment or military service that were perceived as more attractive in the short-term.

Using data from the NELS 88:2000 database, Arbona and Nora (2007) examined the likelihood of Hispanic high school graduates attending either a 2- or 4-year college. The results of a hierarchical logistic regression analysis indicated that the likelihood of attending a 4-year versus a 2-year institution following graduation from high school was influenced by five significant factors. These factors were the student's gender; parental educational expectations as perceived by the student; the 
student's self-concept as it related to English; enrollment in a calculus course in high school; and the perception that most, if not all, of the student's peers planned on attending college.

The results revealed that male Hispanic students, in contrast to female students, were more inclined to enroll in a 2-year college while female Hispanic students were much more likely to attend a 4-year postsecondary institution. Hispanic students' choice of institutional type was also dependent on expectations on the part of their parents that their children would attend college. Those students whose parents had low expectations that their children would attend college were twice as likely to enroll in a community college as opposed to a 4-year higher education institution. Moreover, the more positive a Hispanic student's academic self-concept in science, the more likely they would enroll in a 4-year university. The two most influential factors that predicted enrollment in a 4-year college were taking a precalculus or calculus course while in high school (3.98 times more likely) and knowing that most, if not all, of a student's peers also planned on going to a 4-year institution. It becomes apparent that the choice to attend a community college by Hispanic students is impacted more by a student's academic curriculum and the degree of perceived academic capital than by the social capital received at home.

Nora (2004a) examined the influence of habitus and social capital within the context of both persistence theory and college choice theory. The intent was to test whether factors such as a student's psychosocial experiences during high school (Nora \& Lang, 1999), encouragement and support from family (Nora, 2004a), environmental pull factors (Nora \& Wedham, 1991), and precollege academic performance also contributed in much the same way they did to persistence to a student's choice of college and, subsequently, to the degree of satisfaction (overall, with the institution, and with the intent to reenroll). The results of testing a more holistic model of student college choice and persistence were especially strong regarding the impact of psychosocial factors, specifically habitus, on different measures of college satisfaction experienced by students and their intent to reenroll in college for a second year. In sum, the findings established that students take into consideration such factors as comfort within the university; acceptance by students, faculty, and staff; and the degree of fit between the student and different aspects of the institution.

\section{Factors Influencing Student Retention of Hispanic Students}

Although the literature on college choice as it relates to Hispanic students is still in its infancy, numerous analyses can now be found in the persistence literature making it possible to provide a fuller profile of the different factors that impact on the retention of Hispanic students. This body of knowledge, however, should not be taken to imply that there is no longer a need to further investigate the withdrawal phenomenon among Latinos. As such, the following review of existing literature begins to focus on the many and differential impacts of various academic, social, noncognitive, perceptual, and behavioral variables on the persistence of Hispanic students. 


\section{A Profile of Latinos in Higher Education}

Swail et al. (2005) analysis of data from the NELS:88/00 database found substantial differences between Hispanic and White students with regard to postsecondary persistence and completion. Nearly two thirds (66\%) of Latino students that survived a K-12 educational system and were encouraged to enroll in college failed to earn any degree by 2000 . This figure compares to only $40 \%$ for White students. As discouraging as this may sound, while half of White students earned a bachelor's degree or higher, only $24 \%$ of Latino students accomplished the same. Contributing to the differences in educational attainment among students included attendance patterns, delay of entry into college, time to degree completion, and semester credit hours earned.

Over half $(53 \%)$ of Latino students attend college part-time, compared to only $37 \%$ of White students. Moreover, while $70 \%$ of White students remained continuously enrolled throughout their stay in college, only $44 \%$ of Latino students were able to do the same. And, a five-point gap exists between Latinos (78\%) and White $(83 \%)$ students as to entering postsecondary education within 7 months of graduating from high school. Not only do Latino students take longer to enroll in college but they also need more time to graduate; $44 \%$ of White students earn a degree within 4 years compared to only $23 \%$ of Latino students. Upon closer examination of the first 2 years in college, it was found that $81 \%$ of White students earned 60 or more college credit hours compared to $65 \%$ of Latino students. One logical conclusion is that a large number of Latino students may be dropping out much sooner than other student populations.

Hurtado \& Kamimura (2004) point out that to more fully realize why Hispanic students may not persist to graduation, we must understand that a student's withdrawal decision is contingent on a variety of institutional support structures and college experiences. However, other factors external to an institution have also been found to contribute to a student's resolve to stay in college or, in a far more negative sense, to consider nonacademic options in their lives (dropping out of college). A recent publication of the Center for Higher Education Policy Analysis (CHEPA) identified nine propositions found in the literature that influence student college success including cocurricular activities; a rigorous academic curriculum; academic, college, and career counseling; mentoring; peer support; family and community engagement; incorporating students' cultures in intervention efforts; funding priorities; and the timing of interventions (Tierney et al., 2004).

\section{Cultural and Background Variables}

Two major conclusions reached by DesJardins et al. (2002) were that the quality of the school from where Hispanic students were enrolled made a difference as to whether they persisted or not, and that the socioeconomic status with which minority students enter college negatively affect their retention. However, earlier 
studies by Nora and associates (Nora, 1987; Cabrera et al., 1992, Cabrera 1993) indicated that of the two factors, socioeconomic status as measured by the educational attainment of the student's parents and the total amount of income earned by the family was only minimally associated with a student's integration into his or her social environment and not related to a student's decision to reenroll in college.

The influence of socioeconomic status on the integration of students into a college environment and in predicting college retention and graduation for all students was once more revisited by Hamrick \& Stage (1998), Hurtado et al. (1997), and by Perna (2000). However, their findings demonstrated that socioeconomic status may impact different groups of students in different ways as SES offers benefits to some and limitations or barriers to others (Hurtado et al., 1997; Perna, 2000).

While certain aspects of a student's socioeconomic status may have limited influence, other cultural aspects have been uncovered to significantly impinge on the retention of minority students (Rendon \& Hope, 1996). Among those factors are limited English proficiency, irregular attendance patterns on the part of minority students, being raised in a single parent home, and the quality of a minority student's education prior to college attendance. Moreover, the quality and type of education that minority students receive prior to enrolling in college has been shown to not only keep these students engaged in a higher education but to also predict different measures of college success (Castellanos \& Jones, 2004).

\section{Educational Goal Commitments or Aspirations}

One of the most influential factors on any student's decision to remain enrolled in college is exerted by the educational aspirations of that student. Similarly, prior research has established that Hispanic students' educational hopes play a part in a student's decision to remain in college (Cabrera et al., 1993; Nora et al., 1992). While the impact is encouraging, the discouraging part is that a number of circumstances have been identified that negatively influence the educational aspirations of Hispanic students. These factors include having to deal with family responsibilities, working off-campus as opposed to on-campus, commuting long distances to a college campus, performing poorly in coursework, and perceiving a sense of prejudice and discrimination on a campus (e.g., Nora \& Cabrera, 1996; Cabrera \& Nora, 1994; Cabrera et al., 1992; Nora \& Lang, 2001; Nora, 2002, 2004a).

The strength of this commitment to an educational goal is evident even years after it was first solidified in middle or high school. Perna (2000) found that the desire for a higher education following high school graduation and continuing into graduate school for an advanced degree has a positive and long-lasting influence on the college enrollment rates for Hispanic students. Having a goal in mind from early on remains a driving force so much so that it influences a Hispanic student from withdrawing from college. 


\section{Sense of Belonging}

Another highly important factor for Latino students is the belief that they are part of the academic and social life going on around them (Hurtado Carter, \& Spuler 1996). This sense of belonging on campus subsequently influences a student's desire to remain in college. In an attempt to apply Tinto's theoretical model of student departure to a population of Latino students, Hurtado \& Carter (1997) focused on clarifying the structure of a conceptual model that specified those factors that led to a sense of belonging on the part of the student. The authors tested the extent to which Latino students' background characteristics (i.e., gender and academic self-concept) and academic and social experiences in the first and second years in college contributed to a sense of belonging in the third year. Their findings confirmed that the first-year academic and social experiences of Latino students at 4-year institutions led to a strong sense of belonging at their respective institutions in their third year of college. Hurtado \& Carter established that Hispanic students' sense of belonging on campus was closely linked to the frequency with which they engaged in discussions with other students outside of class, their membership in religious and social-community organizations, and negatively associated with perceptions of a hostile racial climate on their campuses. In other words, in an environment that encourages tolerance and acceptance and engages students and faculty in academic and social discourse, a Latino student's sense that they belong in college and are accepted at that institution is established and nourished.

A recent study conducted by Gloria et al. (2005) assessed the degree to which social support, university comfort, and self-beliefs were interrelated and predictive of undergraduate Hispanic students' decisions to persist. All three constructs were found to be significantly interrelated as well as predictive of student attrition. Individual variables of perceived mentorship, perceptions of social support from friends, and perceptions of the university environment as comforting to Latino students were found to have the strongest predictive value.

\section{Student Engagement}

Padilla et al. (1997) examined the different forms of informal knowledge that are required by minority students to be able to handle their academic and social environments while enrolled in college and to be able to succeed, which they operationally defined as graduating from college. Their findings indicated that sophomore, junior, and senior minority college students that successfully involved themselves at their college campuses took specific actions to overcome four major categories of barriers: discontinuity, lack-of-nurturing, lack of presence, and financial resources.

To overcome any discontinuity barriers (or a disconnect with one's surroundings), successful minority students took actions that would engage them in the different aspects of the academic and social life on their campuses. Such engagement included joining an organization of interest, formulating and making their 
own decisions, and researching the profitability of their own chosen majors. To successfully deal with the issue of nurturing, students confronted issues of selfworth, dealt with their specific needs or sought nurturing from others through support groups or through mentoring resources on his or her campus. The issue of a lack of presence on a university campus involved meeting head-on the institutional culture and practices that devalued and ignored ethnic minority students. Students successfully met such challenges by seeking out an ethnic presence on their respective campuses, fully participating in the activities of ethnic student organizations, and making themselves known on campus one way or another. Finally, successful minority students had to overcome barriers brought on by a lack of resources by preparing and applying early for financial aid, talking to people familiar with the financial aid process, and developing time management skills.

\section{Financial Assistance}

The importance of financial aid within the student persistence process is well established (Cabrera et al., 1990, 1993; Stampen \& Cabrera, 1988). In 1993, Cabrera, Nora, and Castaneda identified an intangible feature associated with financial aid. In addition to the more traditional tangible component considered when investigating financial assistance (the receipt of loans, grants, etc.), the authors believed that affective/ emotional attitudes were associated with different aspects of student finances. Because college costs such as tuition, room and board, and books (to name a few) are stressors in the lives of many minority students, a sense of relief is associated with the ability to meet financial responsibilities through different forms of financial aid. In their study, both the intangible and tangible (financial aid received) components were found to directly and indirectly influence Hispanic student's persistence decisions.

$\mathrm{Hu}$ and St. John (2001) examined the effects of receiving financial aid on the within-year persistence of Hispanic, African-American and White students. Their findings confirmed that the receipt of financial assistance serves an important role in equalizing the playing field and providing opportunities for Hispanic and AfricanAmerican students. In comparing the odds of persisting between those that had received a financial aid package versus those students of each ethnic/racial group that did not receive aid, Hispanic and African-American students who received financial aid were more likely to persist than their nonfinancial aid counterparts.

A recent study of Latino student retention conducted by Longerbeam et al. (2004) examined the reasons for dropping out of college among Latino and nonLatino students. Based on a series of multivariate analyses, significant differences were found between Latino and non-Latino students in the perceptions that most likely led to attrition. Among those factors identified as reasons for dropping out of college among Latino students were financial circumstances, the perception on the part of students that they lacked the academic capital needed to be successful in college, and the desire to enter military service. Embedded within those financial reasons was the expectation to send money home to help with family finances. 


\section{Social Interactions/Experiences}

Very early in the investigation of what contributed to student dropout behavior among undergraduates, Pascarella \& Terenzini (1980) established the importance of the student's social integration on his or her campus. While earlier studies substantiated the influence of a student's social integration within a college environment on their choice to persist in college (e.g., Braxton \& Brier, 1989; Terenzini \& Pascarella, 1977 Bean, 1980;), its conceptualization and importance was questioned as appropriate for minority students (Tierney, 1992; Rendon et al., 2001). Much of the criticism centered on cultural differences that would question whether social integration was forcing an acculturation or assimilation on minorities by proposing that social integration should be applied equally to all groups. The final conclusion reached by some researchers was that the theoretical construct was not an inappropriate variable within persistence models as they applied to minority students but, rather, that the form or manner in which it expressed itself among minorities versus nonminorities was different; that all groups of students are engaged in socially interacting and integrating on a college campus could not be denied. The issues raised were more a matter of measurement and implementation and not the theoretical applicability of the construct (Nora \& Cabrera, 1994).

Studies on minority and nonminority students in 2- and 4-year institutions reveal some overall conclusions regarding the social experiences of Hispanics and their relationship to student persistence. Early on Nora (1987) found that the influence of social experiences, at least in a small way, impacted Hispanic student's decisions to remain enrolled in college. In Nora and Cabrera's (1996) study on the role of perceptions of prejudice and discrimination within a theoretically based model of college persistence, the authors hypothesized that social interactions with peers and faculty were positively influencing student persistence decisions equally for majority and nonmajority college students. In contrast to what had previously been established among White student populations, Nora and Cabrera found that social experiences only had a minimal indirect effect on the persistence of minority students as opposed to Whites where the effect was much more direct. Moreover, Nora et al. (1996) found that student interactions were not significantly related to the persistence of minority students. The indication is that factors other than the social integration of Hispanic students in college may be more important in deciding whether to return to college for a second year. Social experiences of Hispanic students play a much lesser role within the persistence process.

\section{Academic Integration/Experiences}

It comes as no surprise that constructive academic experiences during the first year of college enhance the commitment to earn a college degree and to remain in college on the part of Latino students. Rendon (1994) found that when Latino students 
were engaged in positive and validating classroom and laboratory experiences, study groups, and academic discussions, they were more likely to stick to their goals and to continue to return to college for another academic year.

In one of their earlier studies, Hurtado et al. (1996) focused on those features that affected Latino students' adjustment and attachment to college. One measure of adjustment to college concentrated on academic integration. The authors found the size of the Latino population at a university and the students' perceptions of their interactions with faculty positively influenced the academic adjustment of Latino students. A large concentration of Hispanic students enrolled and positive interactions between students and faculty were identified as two major reasons contributing to the retention of Hispanic students.

\section{Commitment to a Specific Institution}

The desire to attend and graduate from a specific higher education institution has been found to be one of the major influences on student persistence for nonminority students. However, the same research indicates that this commitment to a specific institution has shown mixed findings when it comes to Latino students. While this factor was shown to positively impact student persistence in studies by Braddock (1981), Nora and Cabrera (1993, 1996), and Nora et al. (1992) more recently established that the importance of this commitment to an institution is the number one factor influencing the persistence of White students and it does not play as big a role in reenrollment for Hispanic students. The finding is not that it does not play a role in deciding to return to college, but that other factors outweigh the influence of this commitment.

\section{Academic Performance in College}

In considering the importance of academic performance as it impacts returning or dropping out of college, one should note (or at least be reminded) that the decision to withdraw from college in studies of student retention is voluntary and not based on academic performance. To this end, the impact of a student's academic performance on returning to college is based on the notion that the student has the option to reenroll or to withdraw from college. The most influential factor on a Hispanic student's decision to persist is his or her academic performance (cumulative grade point average) during their first year in college (Nora \& Cabrera, 1996; Nora et al., 1996; Nora, 2004b; Hu \& St. John, 2001). The authors believe that, based on racial/ethnic comparisons, lack of self-efficacy in academically related matters, and self-doubt Hispanics may be more prone to question whether they belong in college and whether they can compete and succeed academically. In other words, a $\mathrm{C}$ average will weigh much more negatively on a 
Hispanic student's decision to return to college than it would for a nonminority student. What the studies revealed was that, for Hispanics, earning less than "good" grades made these students question their ability to attain a college degree. The end result was a sense of giving up and a decision to drop out.

More importantly, though, is the enormous influence that a Latino student's academic performance has on reenrolling in college as the GPA increases. Research by Nora et al. (1997) and Hu and St. John (2001) substantiated the importance of academic performance on the persistence decisions of nontraditional Hispanic students finding that the GPAs of these students have a significant and positive direct influence on those students' decisions to remain in college. Moreover, Nora and Cabrera (1996) found that not only did the academic achievement of Hispanic students have a positive impact on persistence but that even the perceptions that they had made cognitive gains during their first year in college were influential in a Hispanic student's decision to remain enrolled in college.

\section{Environmental Pull Factors}

Early on in the research on student persistence, Nora and Wedham (1991) proposed that a set of environmental pull factors would exert a "pulling away" or a "drawing in" of students into the academic and social campus environments and that, subsequently, these pulls would impact on a student's tenacity to continue a college education. These pulls centered on factors external to university life: having to work off-campus immediately before or after classes, family responsibilities (i.e. taking care of children, siblings, parents, or their entire family), and having to commute to campus. The findings revealed that while working on-campus resulted in a positive pull by providing the opportunity to interact with faculty and peers, working off-campus only increased the chances of dropping out of college.

In much the same way, students that took on serious family responsibilities and could not spend more time on campus to participate in academic and social activities were also very likely to drop out at the end of their first year in college. The inability to spend more time on campus is also embedded within the third pull factor, commuting. As the distance that students needed to drive to attend classes increased, the more likely that the students would choose not to return. The other side of this coin indicated that students residing on campus and not having to leave the campus for work or family provided them with the time necessary to fully integrate both academically and socially at their institutions.

Nora et al. (1999) later examined differences between minority and nonminority male and female students on a national sample of 2- and 4-year institutions on those pull factors earlier identified by Nora and Wedham (1991). Latino and AfricanAmerican students who commuted large distances to campus, who left campus to work elsewhere, and who assumed responsibility to take care of family members before or after classes were less likely to persist in college. The pulling away brought on by family responsibilities was particularly detrimental to female students. 
Women who assumed those household tasks were $83 \%$ more likely to give up attending college and their educational goals.

\section{Cultural Climate/Perceptions of Prejudice and Discrimination}

Critical to the adjustment and engagement of students in college, academically or socially, is an atmosphere of acceptance, tolerance, or rejection by others. The realization that a campus climate is not conducive to student learning, interactions, and engagement is an area of research that has received much attention in the persistence literature. The perception that racial/ethnic tensions continue to exist on campuses even after the advances that were made in recruiting and enrolling Latino students in higher education institutions in the 1970s and 1980s was substantiated by Hurtado (1992) who found that Latino/Latina students tended to perceive the campus climate more negatively when compared to White students. Further evidence was reported by Hurtado (1994) and Nora and Cabrera (1996) who also found that Latino/Latina students reported more discrimination while on campus than White students.

In three separate studies, Nora et al. (Nora \& Cabrera, 1996; Cabrera \& Nora, 1994; Cabrera et al., 1993) established the impact that these perceptions of discriminatory behavior exerted on both the educational aspirations and withdrawal behavior of Hispanics. Student perceptions of prejudice and discrimination on campus, inside as well as outside of the classroom, were extremely harmful to the goal of attaining an undergraduate degree. Of specific importance was the finding that it was not only the direct exposure to discriminatory words and gestures that led to the negative impact on the hopes and expectations of Hispanic students but also to the perception that an environment of intolerance and discrimination existed on their campus and, more specifically, in the classroom.

Although Nora and Cabrera (1996) found that both Hispanic \& White students were just as likely to perceive discriminatory acts and gestures in and outside the classroom, the magnitude with which they were felt was much stronger for Latino students. The perceptions that students are exposed to acts of racial bigotry were realized to have negative effects on the academic performance of students, their social experiences with faculty and peers, students' academic and intellectual development, and on institutional commitment. Moreover, perceptions of discriminatory behaviors were also found to indirectly affect Hispanic student's decisions to persist.

Hurtado et al. (1996) found that Latino/Latina students exposed to a cultural climate on their campuses that they perceived to be hostile were less prone to adjust socially, emotionally, and academically at their institutions. Moreover, Hurtado et al.'s findings held constant regardless of a student's background characteristics, type of institution they attended, or even on the percentage of Hispanic students attending their college.

More recently, Longerbeam et al. (2004) investigated the issue of diversity on a college campus as it related to the persistence of Latino students. The authors' overall conclusions indicated that those Hispanic students that came to perceive their campuses 
as being ethnically diverse were much more likely to remain enrolled. However, even after years of research, Nora (2004b) notes that there exists a lack of minority mentors and role models in our higher education campuses, curricula that does not appropriately address minority issues, and a lack of minority support groups and programs that has led to adverse conditions for Hispanic students that they must somehow overcome.

\section{Family Support}

The importance of a support system through words (and actions) of encouragement and validation by parents has long been established as significantly impacting on student persistence (Cabrera et al., 1993; Nora, 1987; Nora \& Cabrera, 1996). Nora (2004a) notes that encouragement and support come in different forms (e.g., financial, emotional, psychological, etc.) and from different sources (e.g., parents, spouses, professors, etc.). Collectively these different types of encouragement from a variety of people provide a safety net for Latino/Latina students that they come to rely on under stressful and non-stressful circumstances.

Most importantly, la familia has been identified as a major source of support affecting Latino/Latina persistence decisions (Hurtado et al., 1996). The importance of family in the Latino/Latina culture makes it central in considering the impact that a family support system exerts on student persistence (Castellanos \& Jones, 2004). For example, Flores (1992) established that Latino/Latina students whose mothers and fathers provided continuous encouragement to attend college and remain in college increased the likelihood that Hispanic students would persist. Sanchez et al. (1992) found that Latino/Latina students who were not retained reported family and related financial obligations and the need to take on adult roles as major reasons for dropping out of college.

\section{Precollege Psychosocial Experiences}

While specific precollege factors were included in studies that tested Tinto's (1987, 1993) model of student persistence, the operationalization of those factors was limited to the student's entering academic ability, high school rank at time of graduation, and desire to attend college (Pascarella \& Terenzini, 1990). However, Nora and Lang (1999) identified a set of high school psychosocial experiences engaged by students prior to enrolling in college as representing precollege student characteristics. The authors found that past leadership experiences, anticipatory attitudes to attend college, a student's sense of his or her social self-efficacy, close personal relationships with peers, and the importance of attending college expressed by parents significantly impacted a student's transition to a college environment as well as the student's decision to persist. No longer is it thought that the only factors to consider prior to enrollment in college are the student's academic performance in high school, their rank at the time they graduated, or, at most, students' educational aspirations. 


\section{Attitudes Related to Remediation in College}

Most of the studies focusing on student persistence have used student populations from 2- to 4-year institutions relying on minority and nonminority student populations. This line of research centered on identifying, testing, and confirming specific models of student retention and the variables in those studies. Because so many students enter college academically underprepared, many of these students are forced or encouraged to enroll in remedial courses. While the same theoretical constructs apply to these students in establishing those factors that influence subsequent dropout behavior, it was hypothesized by Nora and Garcia (1999) that student perceptions and attitudes related to their remediation would also be likely to impact on their dropout behavior. Some of the most notable factors affecting the withdrawal of development students in negative or positive ways included: the student's perceptions of whether or not they needed to take remedial courses, the value placed on remediation on the part of the student, and the extent to which the student believed that their precollege academic preparation allowed them to develop the necessary competencies to succeed in college. If students did not come to accept the value and utility of remediation and development courses, the likelihood that they would remain enrolled in college was drastically minimized.

\section{Mentoring Experiences}

The importance of mentors and role models for Latino/Latina students has been stressed in the literature (e.g., Castellanos \& Jones, 2004). The authors note that its impact on Hispanic student persistence should not be underestimated. However, only quite recently have researchers started to examine the nature of this construct prior to testing its influence on student retention or its role in the student persistence process, specifically as it relates to the student's adjustment to college. Nora and Crisp (2005, 2008) examined the different dimensions of mentoring, hypothesizing that several subcomponents underlie this much noted factor. The authors believed that extracting the appropriate latent variables underlying a set of items that related to mentoring experiences would uncover or capture the different domains or conceptualization of mentoring. Although the intent of their research focused on establishing the factor structure of mentoring, preliminary results indicated that when introduced within the context of current persistence models, these mentoring components make a contribution in explaining why students drop out of college.

\section{Spirituality}

During the last few years, the topic of spirituality on the part of faculty and students has become quite prevalent. Rendon (in press, 2000) speaks of the "Academics of the Heart" as she engages faculty and researchers to consider a more spiritual 
approach to students in the classroom and in the empirical investigations of undergraduate students. Influenced by this current interest in spirituality among students and faculty, Nora and Anderson (2003) studied the differential impact that religiosity versus spirituality exerted on the adjustment of Hispanic students to college, their academic performance, and on withdrawal decisions within the context of current persistence models. The results of a quantitative data reduction revealed that subcomponents of religiosity focused on the more symbolic expression of a student's religious beliefs while indicators of spirituality focused on the treatment of one another. The findings indicated that while Hispanic students who were more satisfied with the development of their religious philosophy in life were more likely to persist, several components more of a spiritual nature exerted a greater influence on reenrollment decisions. Those Latino students that experienced a positive treatment from others on campus, who reported an overall positive outlook on life, and trusted or had faith in others were much more likely to remain enrolled in college.

\section{An Overview of Policy on Hispanic Educational Opportunity}

This section will examine the impact that state and federal policies/legislation has on Latinos in higher education. This review will focus on the following five major policies/legislation/initiatives: (1) the role of Hispanic-Serving Institutions (HSIs), (2) policy granting in-state tuition to undocumented students, (3) state policy banning the use of race-sensitive criteria in college admission decisions, (4) state percent plans, and (5) the dual enrollment higher education market.

\section{Hispanic-Serving Institutions}

\section{Hispanic Enrollment}

For many Latino students, the pathway to higher education is through a HispanicServing Institution (HSI) as nearly half of all Latino students enroll at an HSI (Laden, 2004; Santiago et al., 2004). HSIs are defined as colleges and universities that enroll $25 \%$ or more full-time equivalent Latino students, with $50 \%$ of that group classified as low-income students (U.S. Department of Education, 2005). In 1997, nearly $90 \%$ of Hispanics were enrolled in HSIs located in California, Texas, New Mexico, New York, Illinois, and Arizona (De Los Santos \& De Los Santos, 2003). Due to the large concentration of Hispanic students in community colleges, over half $(53 \%)$ of all HSIs are community colleges (Benitez \& DeAro, 2004).

Attempts to identify salient characteristics of Hispanic-Serving Institutions and their student outcomes have been minimal (Flores et al., 2006). Two exceptions are recent work by Mulnix et al. (2002) and De Los Santos and De Los Santos (2003). Mulnix et al. (2002) brought attention to the documented disparities in institutional advancement activities which exist between HSIs and other universities around the 
country. According to the U.S. Department of Education (1998) the total revenues of HSIs are $42 \%$ less per full-time equivalent (FTE) student compared to other institutions. Additionally, HSIs report spending $43 \%$ less on instruction, $51 \%$ less on academic support functions, and $27 \%$ less on student services per FTE than other colleges and universities.

Examining the unique challenges/issues facing HSIs, De Los Santos and De Los Santos (2003) surveyed presidents, chancellors, and chief executive officers (CEOs) of HSIs to discuss the three most important concerns facing HSIs in the next few years. The most frequently cited responses included the lack of funding and technology, diversity among their faculty, student growth and diversity, the academic precollege preparation of students, and high attrition rates with corresponding low graduation rates. Although some indicated that the problems faced are generic to higher education, half of the respondents indicated a relationship between the issues faced and being a leader of an HSI.

\section{In-State Tuition for Undocumented Students}

\section{Legislative Action}

Demographers estimate that the total undocumented population in the country is currently ten million of which roughly $80 \%$ are believed to be of Hispanic origin (Pew Hispanic Center, 2005). In response to an increased number of Hispanics wanting to attend college, both federal and state policymakers are currently creating and revising policies related to granting in-state tuition to undocumented students (Biswas, 2005; Olivas, 2004). Section 1623 of the Illegal Immigration Reform and Immigrant Responsibility Act (IIRIRA) of 1996 prohibits states "from providing a post-secondary education benefit to an alien not lawfully present unless any citizen or national of the United States is eligible for such a benefit (in no less an amount, duration, and scope) without regard to whether the citizen or national is such a resident eligible for such benefit" (p. 673).

Another important piece of legislation that may impact undocumented students is the Development, Relief, and Education for Alien Minors (DREAM) Act is presently being debated in Congress. This legislation would repeal Section 1623 of the IIRIRA, eliminating federal penalties to states that provide in-state tuition to undocumented immigrant residents (National Immigration Law Center, 2005; Olivas, 2004). To date, nine states have passed bills into law allowing undocumented students to pay in-state tuition at public institutions and another 24 states have formally considered such legislation. However, even those states that have successfully passed such bills for illegal undocumented students continue to face legislative and legal challenges (Flores et al., 2006). Moreover, several states have recently introduced bills which would restrict in-state tuition for undocumented students. Mississippi is the only state that, by statute, has mandated all undocumented students be classified as nonresidents (Mississippi Code, 1972). 


\section{Race-Sensitive Criteria in College Admissions}

\section{Legislative Action}

In the past, some states (e.g., Texas, California, \& Florida) implemented policies banning the use of race-sensitive criteria in making admission decisions, dramatically affecting the number of Latinos who can gain admission into selective colleges and universities (Tienda, 2001). Decisions by the Fifth Circuit in Hopwood vs. Texas, Proposition 209 in California, and an order by the governor in Florida, known as the One Florida Initiative, are the specific policies and/or legislation which ended race-sensitive admissions (Horn \& Flores, 2003). Following the Hopwood case, states such as Washington, Georgia, \& Florida moved to ban race from their public university admissions policies and enacted alternatives (e.g., Percent Plans) in an attempt to maintain diversity within their institutions (Olivas, 2004). However, the Supreme Court decisions of two cases overturned the Hopwood decision and made the use of race as a plus factor constitutional (Olivas, 2004).

In Grutter vs. Bollinger (2003), the Supreme Court ruled that the use of race as a consideration for admissions did not violate the 14th Amendment of the US Constitution and deferred "to the law school's educational judgment that diversity is essential to its educational mission" (539 U.S. 306, 2003, p. 3). However, in Gratz vs. Bollinger, the ruling specifically stated that the use of an equivalent of a quota system in the admissions procedure was prohibited because "enrolling a 'critical mass' of minority students simply to assure some specified percentage of a particular group merely because of race or ethnic origin would be patently unconstitutional" (539 U.S. 306, 2003, p. 3).

\section{Legislative Impact}

In response to recent rulings, universities have implemented a variety of standard race-neutral admissions practices: (1) a holistic review in which each applicant's file is reviewed in its entirety (e.g., extracurricular activities, letters of recommendation, classes taken, advanced courses taken, GPA) (539 U.S. 306, 2003); (2) merit-based admissions policies, which rely solely on the applicant's high school GPA and/or standardized test scores, without regard to race, ethnicity, socioeconomic status, or class rank (Calcagno \& Alfonso, 2007); (3) class-based or economic-based policies that pay close attention to the economic and social circumstances of the students (e.g., parental income, parental occupation, single-parent household, parental education, school socioeconomic status, neighborhood socioeconomic status, and overall wealth and net worth) (Kahlenberg, 2003; Roach, 2003); and (4) percent plans, in which class rank serves as the primary measure for college admissions, removing the use of standardized test scores as a potential obstacle into higher education and serving as a more democratic means of 
access to colleges and universities, regardless of race and ethnicity (Chapa, 2005; Kahlenberg, 2003).

As expected, state policies in Texas, California, and Florida have negatively impacted the participation of Latinos in higher education. In California, while community colleges do not appear to be significantly affected, the percentage of Hispanic students admitted to, and enrolling at, the University of California (UC) system and the California State University system has been extreme (Rendon et al., 2004). Gándara and Chávez (2003) estimated that the percentage of Hispanic students admitted to the two flagship campuses (UC, Berkeley, \& UCLA) has decreased from an all time high of $15 \%$ to only $8.6 \%$ in 1998, the year Proposition 209 went into effect. The University of California system has not been able to return to the proportion of Hispanic students enrolled prior to Proposition 209 (Gándara, 2005).

\section{State Percent Plans}

\section{Legislative Action}

Specific attempts to address the anticipated negative impact of state policies banning race-sensitive criteria in admissions Texas, California, and Florida have lead to the implementation of percent plans that guarantee admission to state universities or the state university system for the top percentage of high school graduates (Horn \& Flores, 2003). In Texas, House Bill 1678 mandates that the top 10\% of all graduating seniors be admitted to the public university of the student's choice (Montiel, 2002). In contrast, California limits guaranteed admission to only the top 4\%. Furthermore, admission is only guaranteed to a university in the University of California system, not the university of the student's choosing. Similarly, Florida guarantees admission only to the state university system (Horn \& Flores, 2003). However, admission to the university system is granted to an impressive $20 \%$ of graduating seniors (Tienda, 2001).

\section{Legislative Impact}

It is assumed percent plans are at least partially effective in maintaining a racial diversity on the campuses of these states because of the extreme residential segregation that ensures minority representation among the top percentage of students graduating (Tienda, 2001). However, recent findings indicate that percent plans or other raceneutral policies are actually less effective than race-conscious policies in promoting student diversity (American Educational Research Association Amicus Brief). Horn and Flores (2003) and Tienda et al. (2003) recently began to investigate the impacts of each state's plan toward the goal of an ethnically diverse student body. Unfortunately, state plans previously mentioned have shown to have little effect on the majority of students in California \& Florida, simply because admission is only 
guaranteed into the state system which in most cases would be the situation without the plans (Tienda et al., 2003). Findings by Horn and Flores (2003) have also indicated that short-term effects have had the least impact on minority admission to the most competitive campuses, especially in California. It appears that those state plans have the potential to work when used in conjunction with other recruitment and raceattentive outreach programs. However, Horn and Flores' findings also indicated that in some cases, despite the state plan and the existence of retention and outreach efforts, student diversity is not guaranteed (Horn \& Flores, 2003).

\section{Dual Admissions Programs}

\section{Institutional Policy}

Policies related to increasing the number of formal collaborations and partnerships between 2- and 4-year colleges are currently in development at the institutional and state levels (Zamani, 2001). Some of the most notable of these efforts include articulation agreements between transferring and receiving institutions, dual admissions, guaranteed university admissions to students completing Associates' degrees at a community college, and coordinated student support services (Flores et al., 2006). The most comprehensive link between the community college transfer function and the 4-year university system to date is California's Dual Admissions Program (DAP). DAP is designed to grant students who rank in the top 4-12.5\% of their high school-graduating class admission to one of the University of California campuses after successfully completing course requirements at a California community college. Unfortunately, the program is not currently active due to financial/ budgetary circumstances in California (Flores et al., 2006).

\section{Federal/State Programs}

\section{Federal Initiatives}

Major federal programs that support postsecondary education in the United States are authorized by the Higher Education Act (HEA). Among the institutional aid and development programs that have been authorized, the two that directly serve Hispanic students are the Developing Hispanic Serving Institutions (HSIs) Program and the Minority Science and Engineering Improvement Program (MSEIP). The Developing HSIs Program, first authorized in 1994, provides grants to institutions that serve large percentages of Hispanic students (HSIs). This is an important avenue for targeting services to Latino students in higher education as roughly half of Hispanic students are enrolled in HSIs. The MSEIP Program is specifically designed to address the underrepresentation of Hispanic and other minority groups in engineering and 
science fields. Since 2002 the overall initiative has allotted \$8.5 million toward institutional grants aimed at increasing recruitment and supporting Latino students seeking bachelor's degrees in science and engineering (Santiago \& Brown, 2004).

To help prepare low-income students for higher education, HEA has authorized programs such as Gaining Early Awareness and Readiness for Undergraduate Programs (GEAR-UP) and TRIO that includes Upward Bound, Talent Search, and Student Support Services. HEA also authorizes federal grant and loan programs to provide financial assistance to students in the form of Pell Grants, special programs for migrant families, federal supplemental educational opportunity grants (SEOG), Federal Family Education Loan Programs (PLUS), loan forgiveness for teachers and child-care providers, unsubsidized loans, direct loans, College Work Study, and Perkins loans. At the graduate level, HEA supports several national graduate fellowship programs that support education in law, the humanities, and disciplines of national need including the Jacob K. Javits Fellowship Program, Graduate Assistance in Areas of National Need, and Thurgood Marshall Legal Educational Opportunity Program (Santiago \& Brown, 2004).

\section{State Initiatives}

At the state level, a number of programs designed to increase minority access and persistence have been implemented in the past 5-10 years. For instance, GEAR-UP was modeled after several localized programs from around the country. Three of the most notable include the Advancement Via Individual Determination (AVID) Program, Project GRAD (Graduation Really Achieves Dreams), and "I Have a Dream" (Santiago \& Brown, 2004). Another well-known program, The Futures Project, follows urban minority students in diverse educational settings from high school to college. The program is conceptually driven by several theoretical frameworks including sociocultural learning theory, critical pedagogy, and critical sociology (Collatos et al., 2004).

In response to poor transfer rates, the PUENTE Project was implemented in California in 1981. PUENTE provides three areas of service to all community college students: teaching, counseling, and mentoring. As a partnership between the state's community colleges and University of California (UC) system, the program currently serves students in 56 community colleges and 36 high schools throughout the state (Puente, 2006). The project is unique in that it is tailored to affirm Hispanic students' ethnic identities and validate their unique cultural experiences through course offerings (Saenz, 2002).

At the graduate level, organizations such as the Hispanic Border Leadership Institute (HBLI) are being created to better prepare minority educational leaders, largely absent in higher education. HBLI is a doctoral program in educational leadership designed to provide students interaction with influential minority scholars in the field through internships in policy and binational settings. HBLI prepares students to pursue careers in a multicultural environment and foster the educational attainment and persistence of Latino students (Derlin \& Martinez, 1999). 


\section{Evaluation of Federal and State Programs}

Perna and Titus (2005) emphasize the need to examine the effectiveness of existing federal and state programs designed to improve the preparation, recruitment, enrollment, and degree completion of students. Although evaluations of federal and state programs are limited, existing evaluations have shown mixed results that call into question the quality and, in some cases, the integrity of the evaluations. For example, while one evaluation (Laden, 2004) found that $50 \%$ of Puente students transferred to a 4-year institution in a 3-year period, Saenz (2002) reported disappointing results for the same time period that included low high school graduation rates, minimal enrollment rates at the postsecondary level, and high attrition rates during the students' first years in college. Gándara and Bial (2001) identified the program as a template for designing programs geared toward the persistence of Hispanic students in higher education.

National evaluation efforts at assessing the effectiveness of such programs as the National Center for Urban Partnerships (NCUP) and GEAR-UP have been lacking in theoretical soundness and methodological rigor. Initially, the emphasis on outputs rather than on outcomes did little to address the issue of how effective these programs were in affecting student achievement and success. Even when efforts were focused more on outcomes, methodological issues cast doubt on the accuracy of those evaluations. Moreover, the separateness of programmatic and evaluation components associated with these programs was consistently responsible for the lack of rigor in the assessment of activities and outcomes. More often than not, those implementing the programs and those assessing the programs did not collaborate their efforts from the beginning. Evaluation was not taken seriously until the end of the programs when outcomes assessments were requested or required. Oftentimes it was impossible to assess specific outcomes when no baseline data existed.

\section{Best Practices: Implications of What May Work}

While there is still much more to be done on evaluating state and federal initiatives, several characteristics and components of programs targeted at expanding access to, and retention in, higher education for Latino students have surfaced as successful. The following section is not intended to be a detailed profile of activities, practices, and interventions making up those programs but, rather, a summary of general/overall recommendations that are associated with increased Latino access and/or persistence at different institutions. The summary of recommendations is based on pragmatic investigations by CHEPA (2002) on early intervention programs, evaluations by the Building Engineering and Science Talent (BEST) initiative (Building Engineering and Science Talent, 2003), features of effective college-access programs found by Gándara and Bial (2001), principals aimed at providing strategic direction for administrators to increase access and retention rates of Hispanic students at 4-year colleges 
according to Hurtado and Kamimura (2004), and Rendon and Taylor's (1990) tenpoint action plan targeted at community colleges.

\section{Recommendations at the K-12 Level}

\section{Parental Impact}

From early on, Rendon and Taylor (1990) emphasized the involvement of the Hispanic family in the education process. One factor that has consistently been found to influence college enrollment is the early and constant reinforcement of college aspirations provided by family members, specifically by parents. Auerbach (2004) notes that reinforcement of educational aspirations and goals must be done often and in a variety of ways. The author suggests that Hispanic students should research and present college information to their parents at public meetings to attract and build interest.

CHEPA (2002) concluded that all students, parents, and educators should be provided with timely, accurate information. At the junior high and high school level, resources should be provided to students who are at high risk, not on a college-bound track with information regarding those courses that help students prepare for college-level coursework. They strongly urge the mandatory advisement of the college application process before the student's senior year. Furthermore, $\mathrm{K}-12$ should attend to the specialized information needs of Latino parents, such as worries surrounding their children's safety on a higher education campus, undocumented status, and financial aid opportunities and responsibilities. Counselors should also make parents aware of the barriers students may face on campus and the strategies that can be used or overcome them in a sensitive, culturally appropriate way (Auerbach, 2004).

\section{Recommendations at the Postsecondary Level}

\section{Administration/Campus Leadership}

One key factor that must be acknowledged by higher education administrators is the number of faculty of color on their campuses (Gregory, 2003; Hurtado \& Kamimura, 2004). The leadership on campus must also have a strong and genuine commitment to a diverse student body and a sense of inclusiveness across the campus community (Building Engineering and Science Talent, 2003).

More specifically, chief administrative officers must provide a means of rewarding faculty that are successful in developing student talent (Building Engineering and Science Talent, 2003). They should strive to build coalitions between the college, families, business, and the community-at-large (Rendon \& Taylor, 1990). In line with a 
strong commitment to diversity among students and faculty, administrators must examine those dimensions that affect the campus climate (Hurtado \& Kamimura, 2004). Lastly, because so many Hispanic students first enter higher education through community colleges, the transfer function must take on more importance to both 2and 4-year administrators. Linkages with feeder schools should be established and maintained (Building Engineering and Science Talent, 2003; Rendon \& Taylor, 1990).

\section{Student Services}

Auerbach (2004) urges that recruiters reach out to parents in both English and Spanish - especially on the Internet and in college directories and catalogues. The important thing is to make communication with students and parents as personal as possible such as inviting personal stories from guest speakers of similar backgrounds to help families make sense of complex information and feel comfortable asking questions.

Recruitment of targeted Hispanic students can be achieved through executed feeder systems (Building Engineering and Science Talent, 2003). More importantly, Hurtado and Kamimura (2004) stress that recruiters at 4-year universities should utilize more aggressive recruitment strategies, identifying students who are not college bound. The authors further note that institutions must focus on underrepresented areas such as engineering and science programs.

One key suggestion by Gándara and Bial (2001) is the "untracking" of students once they enroll in college. An emphasis should be placed on providing access to the most challenging courses at the university to Hispanic students. They also note that special attention should be paid to financial aid assistance and incentives and that structural elements be incorporated into the campus environment that increases retention.

\section{Campus Climates}

Once students are admitted, institutions must assist those students in navigating the institution (Hurtado \& Kamimura, 2004), implement summer programs for incoming minority and low-income students such as California Alliance for Minority Participation (CAMP) and provide orientation programs designed specifically for minority students and/or low-income first-generational students. In other words, institutions must engage Latino students in the academic and social fabric of the college (Building Engineering and Science Talent, 2003; Gándara \& Bial, 2001; Hurtado \& Kamimura, 2004; Rendon \& Taylor, 1990) such as providing opportunities or avenues for peer support that helps to build social experiences and support institutional commitment and real opportunities for Latinos to participate in student groups/organizations. At the same time, these opportunities must be accompanied by an encouragement of communication and tolerance between racial groups (Hurtado \& Kamimura, 2004). Programs that attempt to change intergroup dynamics, 
formal activities around understanding race and culture (especially important at predominantly White institutions), and activities designed to increase knowledge on campus of Chicano/Chicana and Latino/Latina cultures are especially important at predominantly White institutions.

\section{Faculty}

In addition to providing a climate of acceptance and tolerance, faculty must be strongly encouraged to provide high-quality instruction. This level of instruction can be provided through tutoring and courses specifically designed to meet the needs of Hispanic students (Building Engineering and Science Talent, 2003), by setting high and reasonable faculty expectations of their students and continually measuring their learning and growth (Rendon \& Taylor, 1990), by reinforcing faculty to stay current in their teaching field, and by training faculty to use assessment as a teaching tool (Rendon \& Taylor, 1990).

Hurtado and Kamimura (2004) suggest that faculty identify academic problems early on in the semester and address the issue with the student. A conference at the end of a semester will not provide the student with enough time to engage in any remediation that is necessary. They also stress that faculty must also accept the responsibility of assisting students with managing their time and resources.

\section{Mentoring}

Currently, close attention is being paid to the issue of mentoring undergraduates. While not much specifically has been empirically researched in this area, and there is confusion as to what constitutes a mentoring experience (Nora \& Crisp, 2008), the consensus is that mentoring is beneficial to students and more so to minority students and that it should be long term (Gándara \& Bial, 2001). An important aspect of mentoring is the realistic appraisal of student needs and strengths that help to focus on the unique needs/talents of each student (Building Engineering \& Science Talent, 2003; Nora \& Crisp, 2008). Gándara \& Bial (2001) believe that mentoring should not be engaged in a halfhearted manner, nor should it be assigned simply to other students but that a key person should be formally assigned and responsible for individual students.

\section{Policy Recommendations: A Final Note}

Researchers at Stanford University responsible for the evaluation of their Bridge Program offer several policy recommendations relative to increasing access and postsecondary academic success for Hispanic students. Their most notable recommendations focus on shifting media, policy, and research attention to the $80 \%$ of 
students who do not attend a highly selective university. Access and admissions into flagship universities, while important, will not address the many issues facing Latino students in higher education. Just as important is the need to expand the focus of local, state, and federal programs to include access to success in college rather than the current focus on access exclusively.

A major part of the dilemma with the research on Hispanic students and the evaluation of federal and state initiatives is the lack of theoretically sound longitudinal databases. Typically, state and national databases are not informed by a body of empirical evidence suggesting which variables should be collected and tracked year-to-year. Those databases that may exist at the institutional level and rich in the kinds of constructs captured are not linked to state databases. Even when 2- and 4-year institutions have data on the same set of students, efforts to link the two institutions are nonexistent. Venezia et al. (2003) propose that states should create $\mathrm{K}-16$ databases that can enable researchers and policymakers to monitor and track students' progress.

Ultimately, all interventions and policies can only be informed by research using databases that are longitudinal in nature, conceptually sound, theoretically driven and analyzed with sophisticated statistical techniques. Until attitudinal, behavioral, and perceptual factors are linked to cognitive and noncognitive outcomes, creating appropriate interventions is difficult, assessing those efforts may be misguided and accepting the findings from evaluation studies questionable.

\section{References}

Arbona, C., \& Nora, A. (2007). Predicting college attainment of Hispanic students: Individual, institutional, and environmental factors. The Review of Higher Education, 30(3), 247-270.

Auerbach, S. (2004). Engaging Latino parents in supporting college pathways: Lessons from a college access program. Journal of Hispanic Higher Education, 3(2), 125-145.

Bean, J. P. (1980). Dropouts and turnover. The synthesis and test of a causal model of student attrition. Research in Higher Education, 12, 155-187.

Benitez, M., \& DeAro, J. (2004). Realizing student success at Hispanic Serving Institutions. In B. Vigil Laden (Ed.), Serving minority populations (pp. 35-49). San Francisco, CA: Jossey-Bass.

Biswas, R.R. (2005). Access to community college for undocumented immigrants: A guide for state policymakers. Boston, MA: Jobs for the Future. Retrieved from http://www.jff.org/jff/ PDFDocuments/AccesstoCCUndoc.pdf

Braddock, J.H. (1981). Desegregation and Black students. Urban Education, 15, 43-418.

Braxton, J. M., \& Brier, E. M. (1989). Melding organizational and interactional theories of student attrition. Review of Higher Education, 13, 47-61.

Building Engineering and Science Talent. (2003). Gateways of higher education into America's scientific and technological workforce. San Diego, CA. Retrieved from www.bestworkforce.org

Cabrera, A.F., Castaneda, M.B., Nora, A., \& Hengstler, D. (1992). The convergent and discriminant validity between two theories of college persistence. Journal of Higher Education, 63(2), 143-164.

Cabrera, A.F., \& Nora, A. (1994). College students' perceptions of prejudice and discrimination and their feelings of alienation: A construct validation approach. The Review of Education/ Pedagogy/Cultural Studies, 16(3-4), 387-409.

Calcagno, J. C., \& Alfonso, M. (2007). State merit aid programs: Responses by Florida community colleges. Community College Research Center (CCRC Brief, 35). New York, NY. 
Cabrera, A.F., Stampen, J.O., \& Hansen, W.L. (1990). Exploring the effects of ability to pay on persistence in college. Review of Higher Education, 13(3), 303-336.

Cabrera, A.F., Nora, A., \& Castaneda, M.B. (1993). College persistence: Structural equation modeling test of an integrated model of student retention. Journal of Higher Education, 64(2), $123-137$.

Castellanos, J., \& Jones, L. (2004). Latino/a undergraduate experiences in American higher education. In J. Castellanos \& L. Jones (Eds.), The majority in the minority. Sterling, VA: Stylus.

Ceja, M. (2004). Chicana college aspirations and the role of parents: Developing educational resiliency. Journal of Hispanic Higher Education, 3(4), 338-362.

Cejda, B.D., Casparis, C., \& Rhodes, J. (2002, April). Influences on the educational decisions of Hispanic students enrolled in Hispanic Serving Institutions. Paper presented at the annual conference of the Council for the Study of Community Colleges. Seattle, WA.

Center for Higher Education Policy Analysis. (2002). Making the grade in college prep: A guide for improving college preparation programs. Los Angeles, CA.

Chang, J.C. (2005). Faculty student interaction at the community college: A focus on students of color. Research in Higher Education, 46(7), 770-802.

Chapa, J. (2005). Affirmative action and percent plans as alternatives for increasing successful participation of minorities in higher education. Journal of Hispanic Higher Education, 4(3), 181-196.

Chronicle of Higher Education (2001, August). Almanac Issue: 2001-2. Volume XLVII, \#1

Collatos, A., Morrell, E., Nuno, A., \& Lara, R. (2004). Critical sociology in K-16 early intervention: Remaking Latino pathways to higher education. Journal of Hispanic Higher Education, $3(2), 164-179$.

Contreras, F.E. (2005). Access, achievement, and social capital: Standardized exams and the Latino college-bound population. Journal of Hispanic Higher Education, 4(3), 197-214.

De Los Santos, A.G., \& De Los Santos, G.E. (2003). Hispanic-Serving Institutions in the 21st century: Overview, challenges, and opportunities. Journal of Hispanic Higher Education, 2(4), 377-391.

Derlin, R.L., \& Martinez, M. (1999, April). Leadership and change for the 21st century: Preparing educational leaders to foster persistence and achievement among Hispanic students. Paper presented at the annual meeting of the American Educational Research Association, Montreal, Quebec, Canada.

DesJardins, S.L., Ahlbrug, D.A., \& McCall, B.P. (2002). A temporal investigation of factors related to timely degree completion. Journal of Higher Education, 73 (5), 555-582.

Flores, J.L. (1992, April). Persisting Hispanic America college students: Characteristics that lead to the baccalaureate degree completion. Paper presented at the annual meeting of the American Educational Research Association, San Francisco, CA.

Flores, S.M., Horn, C.L., \& Crisp, G. (2006). Community colleges, public policy, and Latino student opportunity. In C.L. Horn, S.M. Flores, \& G. Orfield's (Eds.), Latino educational opportunity: New directions for Community Colleges. San Francisco, CA: Jossey-Bass.

Fry, R. (2004). Latino youth finishing college: The role of selective pathways. Pew Hispanic Center. Retrieved June 24, 2004 from the Pew Hispanic Center Web site: www.pewhispanic.org

Fry, R. (2005). Recent changes in the entry of Hispanic and White youth into college. Pew Hispanic Center. Retrieved January 28, 2006 from the Pew Hispanic Center website: www. pewhispanic.org

Gándara, P. (1995). Over the ivy wall: The educational mobility of low-income Chicanos. Albany, NY: State University of New York Press.

Gándara, P. (1998). Capturing Latino students in the academic pipeline. California Policy Seminar Brief Series, 10(3). Berkeley, CA: University of California Latino/Latina Policy Research Program.

Gándara, P. (2002). A study of high school Puente: What we have learned about preparing Latino youth for postsecondary education. Educational Policy, 16(4), 474-495.

Gándara, P. (2005). Addressing educational inequities for Latino students: The politics of "forgetting." Journal of Hispanic Higher Education, 4(3), 295-313. 
Gándara, P., \& Bial, D. (2001). Paving the way to postsecondary education: K-12 intervention programs for underrepresented youth. Washington, DC: National Center for Educational Statistics.

Gándara, P., \& Chávez, L. (2003). Putting the cart before the horse: Latinos in higher education. In D. López \& A. Jiménez's (Eds.), Latinos and public policy in California: An agenda for opportunity. Berkeley, CA: Regents of the University of California.

Gregory, S. T. (2003). Planning for the increasing number of Latino students. Planning for Higher Education, 31(4), 13-19.

Gloria, A.M., Castellanos, J., Lopez, A.G., \& Rosales, R. (2005). An examination of academic nonpersistence decisions of Latino undergraduates. Hispanic Journal of Behavioral Sciences, 27(2), 202-223.

Gonzalez, K.P., Stoner, C., \& Jovel, J. (2003). Examining the role of social capital in access to college for Latinas: Toward a college opportunity framework. Journal of Hispanic Higher Education, 2, 146-170.

Harvey, W. B. (2003). Minorities in Higher Education: Annual Status Report. Washington, DC, American Council on Education: 98.

Hamrick, F., \& Stage, F.K. (1998). High minority enrollment, high school lunch rates: Predisposition to college. Review of Higher Education, 21(4), 343-357.

Hoachlander, G., Sikora, A. C., \& Horn, L. (2003). Community college students: goals, academic preparation, and outcomes. Education Statistics Quarterly 5(2), 121-128.

Horn, C.L., \& Flores, S.M. (2003). Percent plans in college admissions: A comparative analysis of three states' experiences. Cambridge, MA: The Civil Rights Project at Harvard University.

Hossler, D., \& Stage, F.K. (1992). Family and high school experience influences on the post secondary educational plans of ninth-grade students. American Education Research Journal, 29(2), 425-451.

Hossler, D., Schmit, J., \& Vesper, N. (1999). Going to college: How social, economic, and educational factors influence the decisions students make. Baltimore, MD: Johns Hopkins University Press.

$\mathrm{Hu}$, S., \& St. John, E.P. (2001). Student persistence in a public higher education system: Understanding racial and ethnic differences. Journal of Higher Education, 72(3), 265-286.

Hurtado, S. (1992). The campus racial climate: Contexts for conflict. The Journal of Higher Education, 63(5), 539-569.

Hurtado, S. (1994). The institutional climate for talented Latino students. Research in Higher Education, 35(1), 21-41.

Hurtado, S., Carter, D. F., and Spuler, A. (1996). Latino student transition to college: Assessing difficulties and factors in successful college adjustment. Research in Higher Education 37(2): $135-157$.

Hurtado, S., \& Carter, D.F. (1997). Effects of college transition and perceptions of the campus racial climate on Latino college students' sense of belonging. Sociology of Education, 70, 324-435.

Hurtado, S., \& Kamimura, M. (2004). Latina/o retention in four-year institutions. In J. Castellanos \& L. Jones' (Eds.), The majority in the minority. Sterling, VA: Stylus.

Hurtado, S., \& Ponjuan, L. (2005). Latino educational outcomes and the campus climate. Journal of Hispanic Higher Education, 4(3), 235-251.

Hurtado, S., Carter, D.F., \& Spuler, A. (1996). Latino student transition to college: Assessing difficulties and factors in successful college adjustment. Research in Higher Education, 37, 135-157.

Hurtado, S., Inkelas, K.K., Briggs, C., \& Rhee, B. (1997). Differences in college access and choice among racial/ethnic groups: Identifying continuing barriers. Research in Higher Education, 38(1), 43-64.

Immerwahr, J. (2003). With diploma in hand: Hispanic high school seniors talk about their future. San Jose, CA: National Center for Public Policy and Higher Education.

Kahlenberg, R. (2003, April). Economic affirmative action in college admissions: A progressive alternative to racial preferences and class rank admissions plans, The Century Foundation, New York, NY.

Laden, B.V. (2004). Hispanic Serving Institutions: What are they? Where are they? Community College Journal of Research and Practice, 28, 181-198.

Llagas, C., \& Snyder, T.D. (2003). Status and trends in the education of Hispanics. Washington, DC: U.S. Department of Education, National Center for Educational Statistics. (NCES 2003-008). 
Longerbeam, S.D., Sedlacek, W.E., \& Alatorre, H.M. (2004). In their own voices: Latino student retention. NASPA Journal, 41(3), 538-550.

McDonough, P. (1997). Choosing colleges: How social class and schools structure opportunity. Albany, NY: State University of New York Press.

Montiel, A. (2002). The recruitment of work-bound, at-risk Hispanic high school students by Texas community colleges. Journal of Hispanic Higher Education, 1(4), 338-350.

Mulnix, M.W., Bowden, R.G., \& Lopez, E.E. (2002). A brief examination of institutional advancement activities at Hispanic Serving Institutions. Journal of Hispanic Higher Education, 1(2), 174-190.

National Center for Education Statistics. (2001). Digest of education statistics, 2001 (NCES No. 2002130). Washington, DC: Author. (ERIC Document Reproduction Number ED455275)

National Center for Education Statistics. (2003). Community college students goals, academic preparation, and outcomes. Postsecondary educational descriptive analysis reports. (NCES No. 2003-164). Washington, DC: Author.

National Research Council. (2006). Multiple Origins, Uncertain Destinies: Hispanics and the American Future. Panel of Hispanics in the United States. Committee on Population, Division of Behavioral, and Social Sciences and Education. Washington, DC: The National Academies Press.

National Immigration Law Center. (2005). Basic facts about in-state tuition for undocumented immigrant students. Los Angeles, CA: National Immigration Law Center. Retrieved from http://www.nilc.org/immlawpolicy/DREAM/in-state_tuition_basicfacts_052405_rev.pdf

Nora, A. (1987). Determinants of retention among Chicano college students: A structural model. Research in Higher Education, 26(1), 31-59.

Nora, A., \& Lang, D. (November, 1999). The impact of psychosocial factors on the achievement, academic and social adjustment, and persistence of college students. Paper presented at the Annual Meeting of the Association for the Study of Higher Education. San Antonio, TX.

Nora, A., \& Lang, D. (June, 2001). Precollege psychosocial factors related to persistence. Paper presented at the Annual Forum of the Association for Institutional Research, Long Beach, CA.

Nora, A. (2002). A theoretical and practical view of student adjustment and academic achievement. In W. Tierney \& L. Hagedorn (Eds.), Increasing access to college: Extending possibilities for all students. Albany, NY: State University of New York Press.

Nora, A., \& Anderson, R.G. (April, 2003). The role of religiosity as a determinant of persistence for minority and nontraditional college students: A logistic regression analysis of a theoretical model of student persistence. Paper presented at the Annual Meeting of the American Educational Research Association, Chicago, IL.

Nora, A. (2004a). The role of habitus and cultural capital in choosing a college, transitioning from high school to higher education, and persisting in college among minority and non-minority students. Journal of Hispanic Higher Education, 3(2), 180-208.

Nora, A. (2004b). Access to higher education for Hispanic students: Real or illusory? In J. Castellanos \& L. Jones (Eds.), The majority in the minority. Sterling, VA: Stylus.

Nora, A., \& Cabrera, A.F. (1993). The construct validity of institutional commitment: A confirmatory factor analysis. Research in Higher Education, 34(2), 243-262.

Nora, A., and Cabrera, A. F. (1994). The Role of Significant Others in the Adjustment and Persistence of Minorities and Nonminorities in Higher Education. Paper presented at the Association for the Study of Higher Education, Tucson, AZ.

Nora, A., Barlow, L. \& Crisp, G. (2006). An assessment of Hispanic students in four-year institutions of higher education. In J. Castellanos, A. M. Gloria, and M. Kamimura (Eds.) The Latina/o Pathway to the Ph.D. (55-78). Sterling VA: Stylus Publishing, LLC.

Nora, A., \& Cabrera, A.F. (1996). The role of perceptions of prejudice and discrimination on the adjustment of minority students to college. Journal of Higher Education, 67(2), 120-148.

Nora, A., \& Crisp, G. (2008). Mentoring students: Conceptualizing and validating the multi-dimensions of a support system. Journal of College Student Retention: Theory and Practice, 9, 337-356.

Nora, A., \& Oliva, M. (2004). College access and the K-16 pipeline: Connecting policy and practice for Latino student success. Journal of Hispanic Higher Education, 3(2), 117-124. 
Nora, A., \& Wedham, E. (1991, April). Off-campus experiences: The pull factors affecting freshman-year attrition on a commuter campus. Paper presented at the annual meeting of the American Educational Research Association, Chicago, IL.

Nora, A., Castaneda, M.B., \& Cabrera, A.F. (1992). Student persistence: The testing of a comprehensive structural model of retention. Paper presented at the annual conference of the Association for the Study of Higher Education, Minneapolis, MN.

Nora, A., Cabrera, A.F., Hagedorn, L.S., \& Pascarella, E.T. (1996). Differential impacts of academic and social experiences on college-related behavioral outcomes across different ethnic and gender groups at four-year institutions. Research in Higher Education, 37 (4), 427-451.

Nora, A., Kraemer, B., \& Hagedorn, L. (1997, November). Persistence among non-traditional Hispanic college students: A causal model. Paper presented at the annual meeting of the Association for the Study of Higher Education, Albuquerque, New Mexico.

Nora, A., Rendon, L.I., \& Cuadraz, G. (1999). Access, choice, and outcomes: A profile of Hispanic students in higher education. In A. Tashakkori \& H.S. Ochoa (Eds.), Readings on equal education: Education of Hispanics in the U.S.: Policies, practices and outcomes (Vol. 16). New York: AMS Press.

Nora, A., \& Garcia, V. (April, 1999). Attitudes related to remediation among developmental students in higher education. Paper presented at the Annual Meeting of the American Educational Research Association. Montreal, Canada.

Nora, A., Barlow, L., \& Crisp, G. (2005). An assessment of Hispanic students in four-year institutions of higher education. In J. Castellanos, A. M. Gloria, \& M. Kamimura (Eds.), The Latinalo pathway to the Ph.D. Sterling, VA: Stylus, LLC.

Nora, A., \& Crisp, G. (2005, November). Mentoring students: Conceptualizing and validating the multi-dimensions of a support system. Presented at the 30th Annual Meeting of the Study of Higher Education, Philadelphia, PA.

Olivas, M.A. (2004). IIRIRA, the dream act, and undocumented college student residency. Journal of College and University Law, 30. J.C. \& U.L. 435.

Ornelas, A., \& Solórzano, D. (2004). The transfer condition of Latina/o community college students in California: Policy recommendations and solutions. Community College Journal of Research and Practice, 28, 233-248.

Ortiz, V. (1986). Generational status, family background, and educational attainment among Hispanic youth and non-Hispanic white youth. In Michael A. Olivas (ed.), Latino College Students. New York: Teachers' College Press.

Padilla, R., Trevino, J., Gonzalez, K., \& Trevino, J. (1997). Developing local models of minority student success in college. Journal of College Student Development, 38(2), 125-135.

Pascarella, E.T., \& Terenzini, P.T. (1980). Predicting freshman persistence and voluntary dropout decisions from a theoretical model. Journal of Highter Education, 51, 60-75.

Perna, L.W. (2000). Differences in the decision to attend college among African Americans, Hispanics, and Whites. The Journal of Higher Education, 71(2), 117-141.

Perna, L.W., \& Titus, M.A. (2005). The relationship between parental involvement as social capital and college enrollment: An examination of racial/ethnic group differences. The Journal of Higher Education, 76(5), 485-518.

Pew Hispanic Center. (2005). Hispanics: A people in motion. Washington, DC: Pew Hispanic Center.

President's Advisory Commission on Educational Excellence for Hispanic Americans. (2002). The Road to a College Diploma: The Complex Reality of Raising Educational Achievement for Hispanics in the United States. Washington, DC.

Puente Project. (2006). The Puente Project homepage. Retrieved at: http://www.puente.net/

Rendon, L.I. (1994). Validating culturally diverse students: Toward a new model of learning and student development. Innovative Higher Education, 19(1), 23-32.

Rendon, L.I., \& Hope, R.O. (1996). Educating a new majority: Transforming America's educational system for diversity. San Francisco, CA: Jossey-Bass. 
Rendon, L., \& Taylor, M. (1990). Hispanic students: Action for access. Community, Technical, and Junior College Journal, 60(3), 19-22.

Rendon, L. I. (2000). Academics of the heart: Reconnecting the scientific mind with the spirit's artistry. The Review of Higher Education, 24(1), 1-13.

Rendon, L.I., Jalomo, R., \& Nora, A. (2001). Minority student persistence. In J. Braxton's (Ed.), Rethinking the departure puzzle: New theory and research on college student retention. Vanderbilt University Press: Nashville.

Rendon, L. I., Novack, V., \& Dowell, D. (2005). Testing race-neutral admissions models: Lessons learned from California State University-Long Beach. The Review of Higher Education, 28(2), 221-243.

Roach, R. (2003). Class-Based affirmative action. Black Issues in Higher Education, 20(9), $22-26$.

Saenz, V.B. (2002). Hispanic students and community colleges: A critical point for intervention. University of California, Los Angeles: ERIC Digest.

Sanchez, J., Marder, F., Berry, R., \& Ross, H. (1992). Dropping out: Hispanic students, attrition and the family. College and University, 67, 145-150.

Santiago, D.A., \& Brown, S. (2004). Federal policy and Latinos in higher education. Washington, DC: Pew Hispanic Center.

Santiago, D.A., \& Cunningham, A.F. (2005). How Latino students pay for college: Patterns in financial aid in 2003-04. Washington, DC: Excelencia in Education, Institute for Higher Education Policy.

Santiago, D.A., Andrade, S.J., \& Brown, S.E. (2004). Latino student success at Hispanic-serving institutions. Washington, DC: Excelencia in Education, Inc. Retrieved from http://www.cierp. utep.edu/projects/lss/pbrief.pdf

Smedley, B. D., Myers, H. F., \& Harrell, S. P. (1993). Minority-status stresses and the college adjustment of ethnic minority freshman. Journal of Higher Education, 64(4), 434-452.

Solorzano, D.G., Villalpando, O., \& Oseguera, L. (2005). Educational inequities and Latina/o undergraduate students in the United States: A critical race analysis of their educational progress. Journal of Hispanic Higher Education, 4(3), 272-294.

Stampen, J.O., \& Cabrera, A.F. (1988). Is the student aid system achieving its objectives: Evidence on targeting and attrition. Economics of Education Review, 7, 29-46.

Swail, W.S., Cabrera, A.F., Lee, C., \& Williams, A. (2005). Latino students and the educational pipeline. Washington, DC: Educational Policy Institute.

Terenzini, P. T., \& Pascarella, E. T. (1977). Voluntary freshman attrition and patterns of social and academic integration in a university: A test of a conceptual model. Research in Higher Education, 6, 25-43.

Tienda, M. (2001). College admission policies and the educational pipeline: Implications for medical and health professions. Princeton, NJ: Texas Higher Education Opportunity Project at Princeton University.

Tienda, M., Leicht, K., Sullivan, T., Maltese, M., \& Lloyd, K. (2003). Closing the gap?: Admissions and enrollments at the Texas public flagships before and after affirmative action. Princeton, NJ: Texas Top 10\% Project.

Tierney, W. (1992). An anthropological analysis of student participation in college. Journal of Higher Education, 63(6), 603-618.

Tierney, W.G., Corwin, Z.B., \& Colyar, J.E. (Eds.). (2004). From high school to college: Evaluating access. Albany, NY: SUNY Press.

Tinto, V. (1987). Leaving College: Rethinking the Causes and Cures of Student Attrition. Chicago: University of Chicago Press.

Tinto, V. (1993). Leaving college: Rethinking the causes and cures of student attrition. Chicago: University Chicago Press.

U.S. Department of Education. (1998). Fact sheet: Title III institutions. Washington, DC: Government Printing Office.

U.S. Department of Education. (2005). Title V developing Hispanic-serving institution programs. Retrieved from http://www.ed.gov/programs/idueshsi/definition.html 
U.S. Department of Commerce (2001). Bureau of the census, the Hispanic population in the United States. Washington, DC.

Venezia, A., Kirst, M.W., \& Antonio, A. (2003). Betraying the college dream: How disconnected $K-12$ and postsecondary education systems undermine student aspirations. Stanford, CT: The Bridge Project.

Zarate, M. E., \& Gallimore, R. (2005). Gender differences in factors leading to college enrollment: A longitudinal analysis of Latina and Latino students. Harvard Educational Review, 75(4), 383-408.

Zamani, E.M. (2001). Institutional responses to barriers of the transfer process. New Directions for Community Colleges, 114, 15-24. 
